\title{
Landfill Gas to Energy: A Demonstration Controlled Environment Agriculture System
}

\author{
Harry Janes, ${ }^{1}$ James Cavazzoni, Guna Alagappan, David Specca, and Joseph Willis \\ Room 184 Foran Hall, Cook Campus, 59 Dudley Road, Department of Plant Biology and Pathology, Rutgers, the \\ State University of New Jersey, New Brunswick, NJ 08901-8520
}

\begin{abstract}
Additional index words. aquaculture, controlled environment agriculture, energy conservation, greenhouse gas emissions, landfill gas-to-energy

Summary. A qualitative systems approach to controlled environment agriculture (CEA) is presented by means of several multi-institutional projects integrated into a demonstration greenhouse at the Burlington County Resource Recovery Complex (BCRRC), N.J. The greenhouse has about 0.4 ha of production space, and is located about $800 \mathrm{~m}$ from the about 40 -ha BCRRC landfill site. A portion of the landfill gas produced from the BCRRC site is used for microturbine electricity generation and for heating the greenhouse. The waste heat from the turbines, which are roughly $15 \mathrm{~m}$ from the greenhouse, is used as the main heat source for the greenhouse in the winter months, and to desalinate water when heating is not required. Recovery of this waste heat increases the energy efficiency of the four $30-\mathrm{kW}$ turbines from about $25 \%$ to $75 \%$. Within the greenhouse, aquaculture and hydroponic crop production are coupled by recycling the aquaculture effluent as a nutrient source for the plants. Both the sludge resulting from the filtered effluent and the inedible biomass from harvested plants are vermicomposted (i.e., rather than being sent to the landfill), resulting in marketable products such as soil amendments and liquid plant fertilizer. If suitably cleaned of contaminants, the $\mathrm{CO}_{2}$ from the landfill gas may be used to enrich the plant growing area within the greenhouse to increase the yield of the edible products. Landfill gas from the BCRRC site has successfully been processed to recover liquid commercial grade $\mathrm{CO}_{2}$ and contaminant-free methane- $\mathrm{CO}_{2}$, with the potential for this gas mixture to be applied as a feedstock for fuel cells or for methanol production. Carbon dioxide from the turbine exhaust may also be recovered for greenhouse enrichment. Alternatively, algal culture may be used to assimilate $\mathrm{CO}_{2}$ from the turbine exhaust into biomass, which may then be used as a biofuel, or possibly as fish feed, thus making the system more self-contained. By recycling energy and materials, the system described would displace fossil fuel use, mitigating negative environmental impacts such as greenhouse gas emissions, and generate less waste in need of disposal. Successful implementation of the coupled landfill (gas-to-energy $\cdot$ aquaponic - desalination) system would particularly benefit developing regions, such as those of the Greater Caribbean Basin.
\end{abstract}

A qualitative systems approach to controlled environment agriculture is presented by means of several multi-institutional projects integrated into a demonstration greenhouse at the Burlington County Resource Recovery Complex, N.J. The partners for the projects described here are the U.S. Environmental Protection Agency (USEPA)-Region 2, Rutgers University, Metropolitan University-Puerto Rico, and the University of the Virgin Islands. One objective of the USEPA funding for this partnership is to facilitate technology transfer to the Greater Caribbean Basin region.

Municipal solid waste (MSW) landfills are the largest human-generated source of methane emissions in the U.S. (USEPA, 2003). For the United States, $57 \%$ of municipal solid waste generated in 2000 , or about 100 million metric tons, were discarded into landfills (USEPA, 2001). The biodegradable organic material in the landfills undergoes anaerobic decomposition, essentially producing about $50 \%$ carbon dioxide $\left(\mathrm{CO}_{2}\right)$ and $50 \%$ methane $\left(\mathrm{CH}_{4}\right)$, with trace concentrations of other gases. In addition to posing local safety concerns, the methane produced from

Fig. 1. A schematic of the energy and material flows for the system at the Burlington County Resource Recovery Complex (BCRRC) and Demonstration Greenhouse.

U.S.Environmental ProtectionAgency-Region 2 has provided support for the installation of the LFG-fueled microturbine and desalinization system, and for demonstration of the aquaponic and algal culture systems at the BCRRC greenhouse site.

'Corresponding author; e-mail janes@aesop.rutgers. edu.

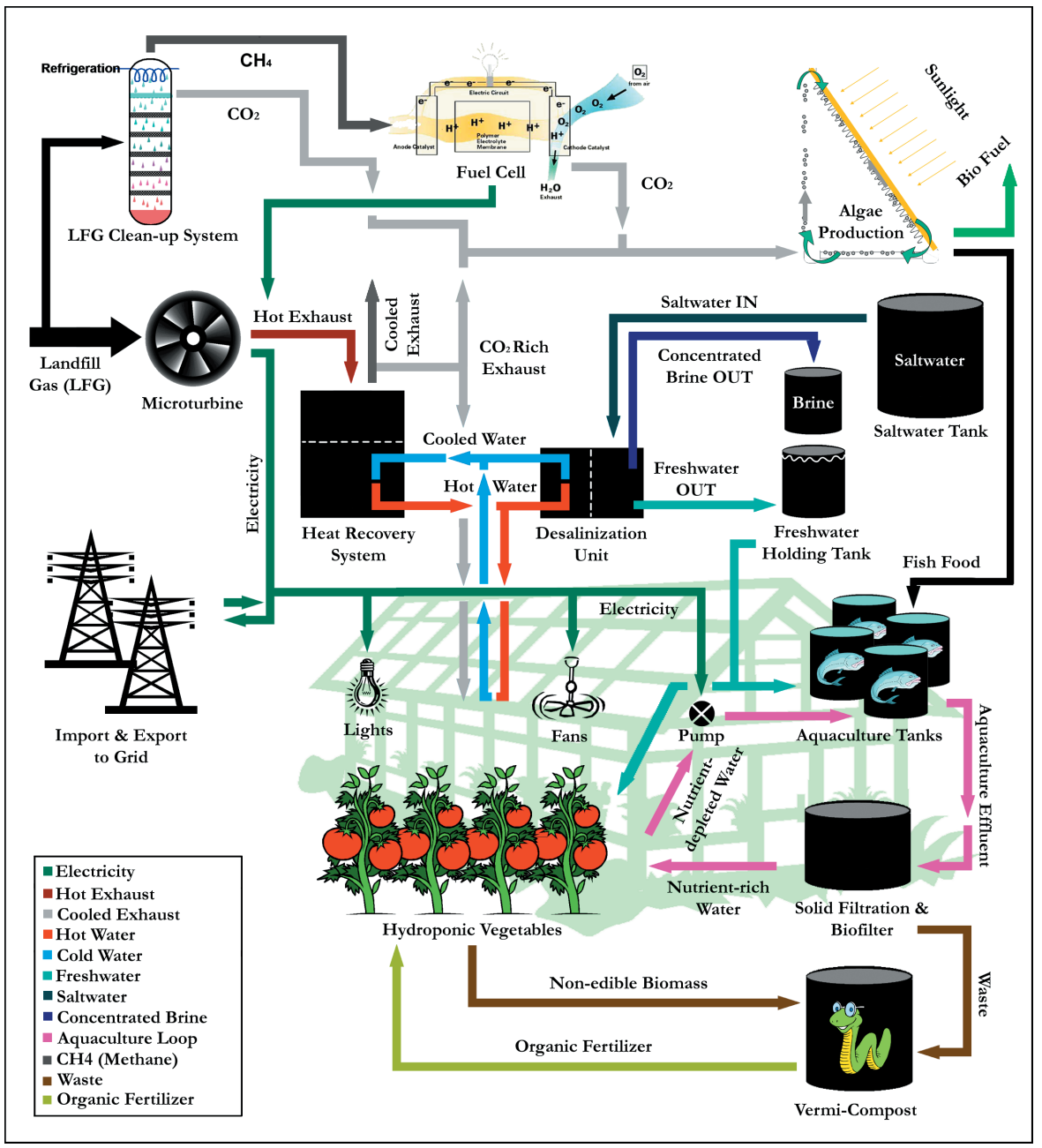




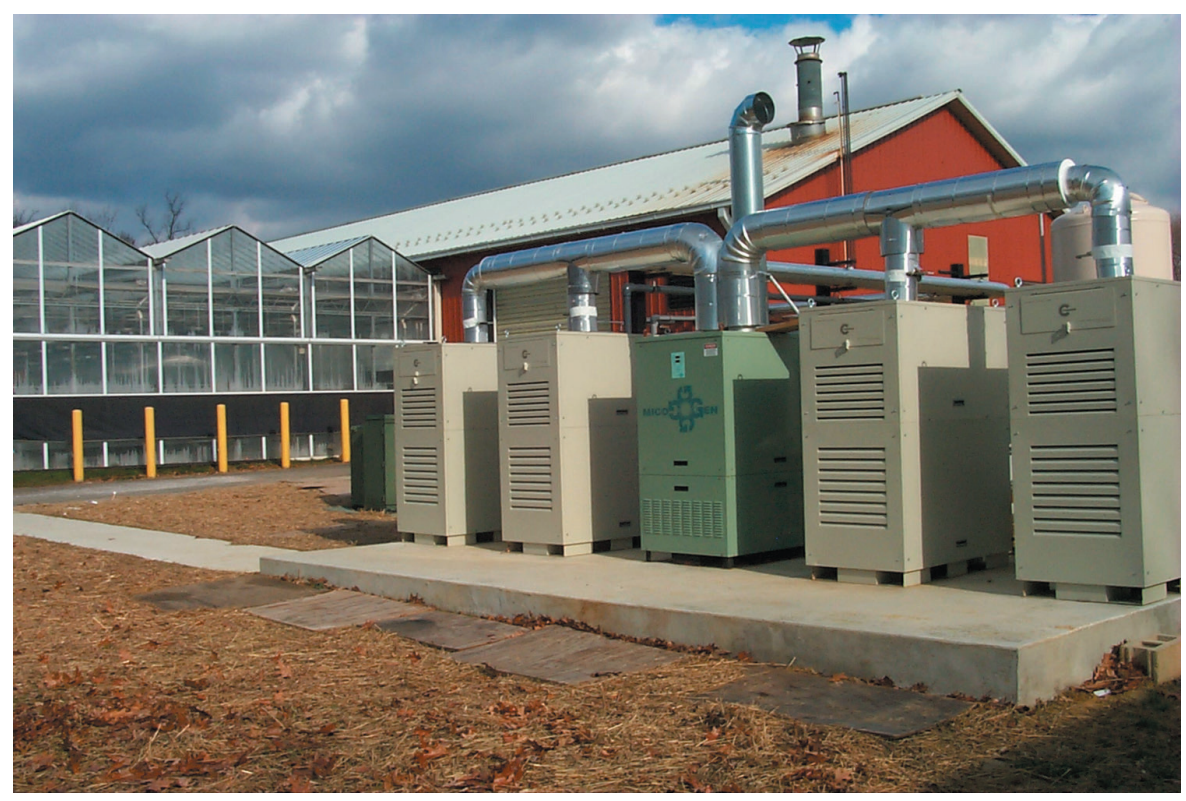

Fig. 2. The micro-turbine system at the BCRRC demonstration site. The electric power output for each turbine is $30 \mathrm{~kW}_{\mathrm{E}}$. The greenhouse facility is in the background.

landfills constitutes a major source of emissions worldwide (White et al., 1995).

The USEPA mandates collection and flare of landfill gas (LFG) to prevent subsurface migration of methane, to convert methane to $\mathrm{CO}_{2}$ (a less potent greenhouse gas than methane) and to oxidize contaminants. Of the estimated 2,500 MSW landfills currently operating in the United States, the USEPA estimates that more than 600 could use LFG for energy, producing enough electricity to power over 1 million homes, and displacing a corresponding amount of fossil fuel use (USEPA, 2003). The requirement to flare LFG means mandatory gas collection systems and the associated maintenance, which creates opportunities to use the LFG for energy rather than flaring. One such opportunity is described here for the demonstration greenhouse at the Burlington County Resource Recovery Complex.

\section{The Demonstration System}

\section{Overview}

The demonstration system is depicted in Fig. 1. A portion of the LFG produced from the Burlington County Resource Recovery Complex (BCRRC) landfill site is used for microturbine electricity generation and for heating the greenhouse. The waste heat from the turbines is used as the main heat source for the greenhouse in the winter months, and to desalinate water when heating is not required. Within the greenhouse, aquaculture and hydroponic crop production are coupled by recycling the aquaculture effluent as a nutrient source for the plants. Both the sludge resulting from the filtered effluent and the inedible biomass from harvested plants are vermicomposted, rather than being sent to the landfill, resulting in marketable products such as soil amendments and liquid plant fertilizer. If suitably cleaned of contaminants, the carbon dioxide $\left(\mathrm{CO}_{2}\right)$ from the landfill gas or from the turbine exhaust
The inputs to a landfill system occur over the working life of the site, while the LFG outputs continue after closure. In 2002, about 300,000 t of solid waste was landfilled in the open cell at the BCRRC site, of which about $220,000 \mathrm{t}$, or $72 \%$, was municipal waste (R. Simkins, Burlington County Resource Recovery Complex, personal communication). An approximate, average value for the landfill gas generated per metric ton of municipal waste (i.e., from the biodegradable components) may be taken to be $150 \mathrm{~m}^{3} \cdot \mathrm{t}^{-1}$ (wet) material (White et al., 1995). The heating value for the gas depends on the methane content, but typically ranges from 15 to $20 \mathrm{MJ} \cdot \mathrm{m}^{-3}$ (compared to about $37 \mathrm{MJ} \cdot \mathrm{m}^{-3}$ for $\mathrm{CH}_{4}$ ). Thus, at $18 \mathrm{MJ} \cdot \mathrm{m}^{-3}$, the municipal waste landfilled at the BCRRC site in 2002 alone represents the eventual release of about $30 \times 10^{6} \mathrm{~m}^{3}$ of LFG, or more than $500 \times 10^{6}$ MJ. In 2003, about $130,000 \mathrm{~m}^{3} \cdot \mathrm{d}^{-1}$ of LFG was flared at the BCRRC site, which amounts to almost $30 \mathrm{MW}$ of primary energy being combusted without recovery.

\section{Landfill gas to energy}

LFG generation typically begins after waste disposal and may continue for 20 or 30 years after the landfill is closed. Generation peaks shortly after closure, and then gradually declines over a number of years (USEPA, 2003). Landfill leachate is a complex organic liquid formed primarily by the percolation of precipitation water through the open landfill or through a pervious soil cap of the completed site. The leachate may be recirculated through the landfill to increase moisture content and mixing, thus enhancing methane production (Britz, 1995). In this way, as for the active cell at the BCRRC site, the landfill may be run as a bioreactor, i.e., essentially controlling the moisture content of the landfill.

Even though LFG collection is mandatory in the U.S., the LFG must be sent from the landfill to the micro-turbines. The capital cost of this for the system of pipes and blowers

at the BCRRC demonstration site, where

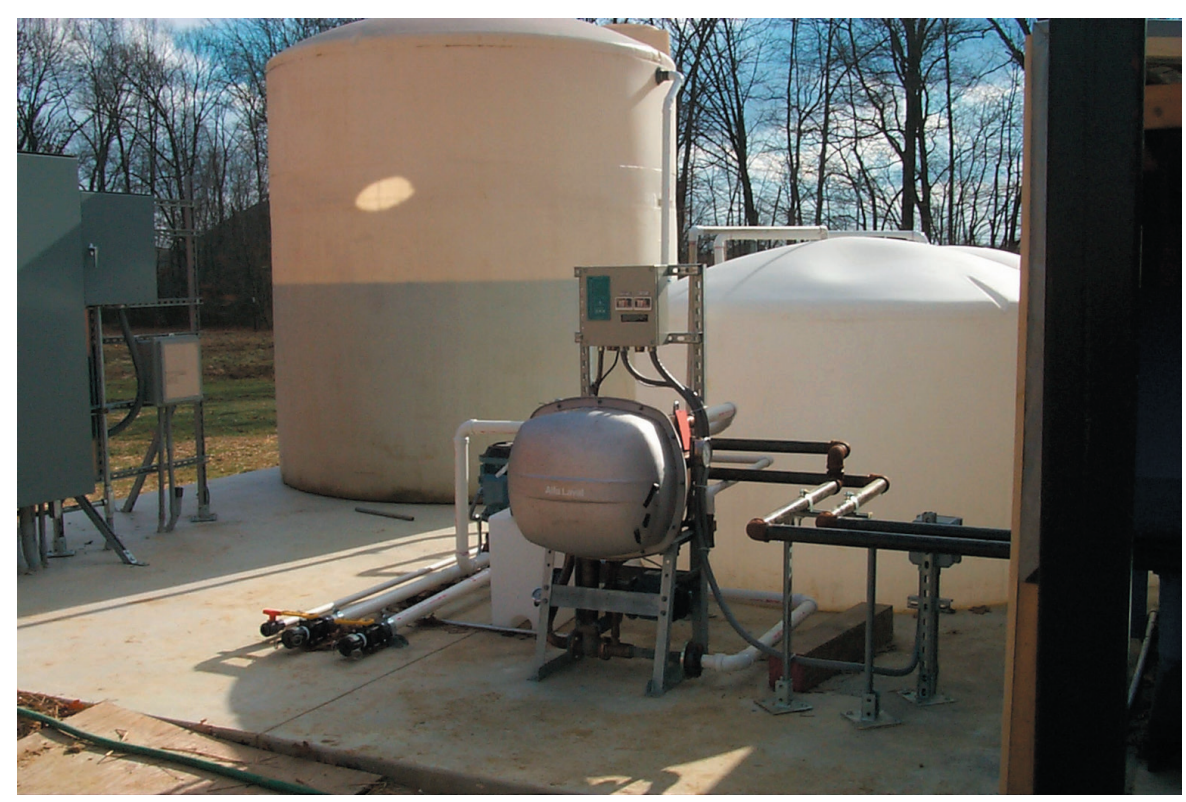

Fig. 3. The waste-heat desalination unit at the BCRRC demonstration site. 
Table 1. Private partners demonstrating technologies at the BCRRC site.

\begin{tabular}{lll}
\hline Acrion Technologies, Inc. & http://ww w.acrion.com & Cleveland, Ohio \\
Terracycle, Inc. & www.terracycle.ca & Princeton, N.J. \\
Greenfuel Corporation & www.greenfuelonline.com & Cambridge, Mass. \\
\hline
\end{tabular}

the micro-turbines are located about $800 \mathrm{~m}$ away from the landfill, is estimated to be about $\$ 100,000$. Adding another $10 \%$ for engineering costs and a $25 \%$ contingency factor increases this to about $\$ 140,000$. The county may also charge for the LFG, which is typically indexed to the price of natural gas, based on methane content, with some discount for installation cost.

Microturbines, with capacities ranging from about 30 to $100 \mathrm{~kW}_{\mathrm{E}}$ (electric power output), are a relatively new technology that may be used in LFG applications to generate electricity for onsite use. The BCRRC site uses four $30-\mathrm{kW}_{\text {microturbines (Fig. 2), which }}$ cost about $\$ 200,000$. The gas as delivered from the landfill is saturated with water vapor and contains trace impurities. The LFG is thus first compressed, dewatered and filtered before being sent to the micro-turbines; each step having a corresponding dollar and energy cost. For the BCRRC system, this ancillary equipment added perhaps another $\$ 100,000$ to the cost. Thus the capital cost for the BCRRC landfill-gas-to-energy for the microturbines at the demonstration greenhouse was about $\$ 450,000$ (Simkins, 2003).

The landfill gas sent to the micro-turbines is about $0.03 \mathrm{~m}^{3} \cdot \mathrm{s}^{-1}$ with an energy content ranging from 18 to $19 \mathrm{MJ} \mathrm{m}^{-3}$, which corresponds to about $550 \mathrm{~kW}$ of primary energy. The power input for each of the micro-turbines is about $120 \mathrm{~kW}$, or $480 \mathrm{~kW}$ for all four, which at $25 \%$ efficiency gives $120 \mathrm{~kW}_{\mathrm{E}}$ electrical power output. Assuming an $85 \%$ availability factor, the displaced electricity generation amounts to about $890,000 \mathrm{~kW}$-h/year, which at $\$ 0.12 \mathrm{~kW}-\mathrm{h}^{-1}$ savings would take 4 to 5 years to recover the capital costs for this test system. The fossil fuel displaced by generating electricity from the microturbine system amounts to avoiding the emissions of about $480 \mathrm{t}^{\text {-year }}{ }^{-1}$ of $\mathrm{CO}_{2}, 4 \mathrm{t} \cdot \mathrm{year}^{-1}$ of $\mathrm{SO}_{2}$, and $1 \mathrm{t} \cdot$ year $^{-1} \mathrm{NO}_{\mathrm{x}}$. [From PJM (Pennsylvania, New Jersey, Maryland) interconnection, a consortium of electric power suppliers in the Northeast U.S. (http://www.newenergy. $\mathrm{com} / \mathrm{press} /$ detail.cfm?nid $=652 \&$ sid $=16$ ) the emissions, on average, for the power generation sources in the PJM region (primarily coal and nuclear) amounts to $538 \mathrm{~kg}$ of carbon dioxide, $4.6 \mathrm{~kg}$ sulfur dioxide $\left(\mathrm{SO}_{2}\right)$ and $1.3 \mathrm{~kg}$ nitrogen oxides $\left(\mathrm{NO}_{\mathrm{x}}\right)$ per megawatt-hour of electricity generated. For $\mathrm{NO}_{\mathrm{x}}, 0.32 \mathrm{~kg} \mathrm{MW-}$ $\mathrm{h}^{-1}$ is subtracted for the estimated microturbine emissions (USEPA, 2003)].

This equivalent $\mathrm{CO}_{2}$ displacement amounts to planting about 65 ha of forest per year. [This assumes $2 \mathrm{t}$ carbon per ha per year sequestered in a U.S. type agroforest system (Dixon et al., 1994). This calculation is for the fossil fuel $\mathrm{CO}_{2}$ displacement, not for the equivalent avoided methane release from the landfill, as flaring LFG is mandatory in the U.S.]

About another $0.07 \mathrm{~m}^{3} \cdot \mathrm{s}^{-1}$ of LFG is sent to a dual-fueled boiler in the greenhouse for back-up heat. This boiler operates at $80 \%$ efficiency, and may also use natural gas. However, the waste heat from the turbines is used as the main heat source for the greenhouse in the winter months, and to desalinate water when heating is not required. Recovery of this waste heat increases the energy efficiency of the four $30-\mathrm{kW}$ turbines from about $25 \%$ to $75 \%$. For the desalination unit, the waste heat is used to distill the feed water (sea water or brine), with the cleaned fresh water vapor condensed and collected, and the concentrated brine accumulated in a sump for return to the water source, or for wastewater treatment. The waste-heat desalination unit is shown in Fig. 3.

\section{LFG clean-up technologies}

In addition to the research universities and the county, the partnership for the demonstration system involves a handful of start-up companies (Table 1). Acrion Technologies, Inc., has conducted a technology demonstration at the BCRRC site of equipment designed to recover contaminant-free methane-carbon dioxide and liquid commercial grade $\mathrm{CO}_{2}$ from landfill gas. The $\mathrm{CO}_{2}$ recovered from this technology would be suitable for enriching the plant growing area within the greenhouse to increase the yield of the edible product, for instance. The gas mixture may potentially be applied as a feedstock for fuel cell or for methanol production, and may be further refined to pipeline natural gas. Product scenarios include pipeline gas and liquid $\mathrm{CO}_{2}$, liquid methane and liquid $\mathrm{CO}_{2}$, and methanol, in order of increasing capital investment. Capital investment for a modest (BCRRC) size about $100,000 \mathrm{~m}^{3} \cdot \mathrm{d}^{-1} \mathrm{LFG}$ plant is estimated to be about $\$ 8$ million for pipeline gas and liquid $\mathrm{CO}$ recovery, to $\$ 12$ million for methanol production (http://www.acrion.com). $\mathrm{m}$ growing area.

\section{Research Greenhouse and Hydroponic Crop Production}

The basic energetics of hydroponic crop production involves converting light energy, $\mathrm{CO}_{2}$, water, and nutrients into plant biomass via photosynthesis and biosynthesis. Biosynthesis refers to converting photosynthate into plant biochemical components (carbohydrates, proteins, lipids, organic acids and minerals) with the requisite growth respiration energy costs. The direct energy needs for controlled environment agriculture include, for instance, electric lighting to supplement natural light, heating and cooling with the associated fans and blowers, and pumps to recirculate the nutrient solution. The indirect energy costs include, for instance, the embodied energy in the fertilizer (e.g., production and transport), water supply, and human labor.

The demonstration greenhouse at the BCRRC is about $15 \mathrm{~m}$ from the microturbine system. Designed by the Bioresource Engineering Department of Cook College, Rutgers University and built by the County of Burlington's Board of Chosen Freeholders, the greenhouse has numerous environmental technologies incorporated into its design. In addition to using electricity and heat generated from $L F G$, the research facility includes other noteworthy features:

- Sophisticated computerized environmental controls for five separate zones that monitor, control, and record the temperature, light level, humidity and carbon dioxide level for each zone while minimizing energy usage.

- Heated floors throughout that serve as a thermal storage device for providing heat to the crops efficiently.

- High intensity lighting to supplement natural sunlight and extend the day length during the lower-light periods of the year (September through April).

- Energy curtains that reduce heat loss, during the night, in winter and reduce the cooling loads, during the day, in summer.

- High-density polyethylene liners under the

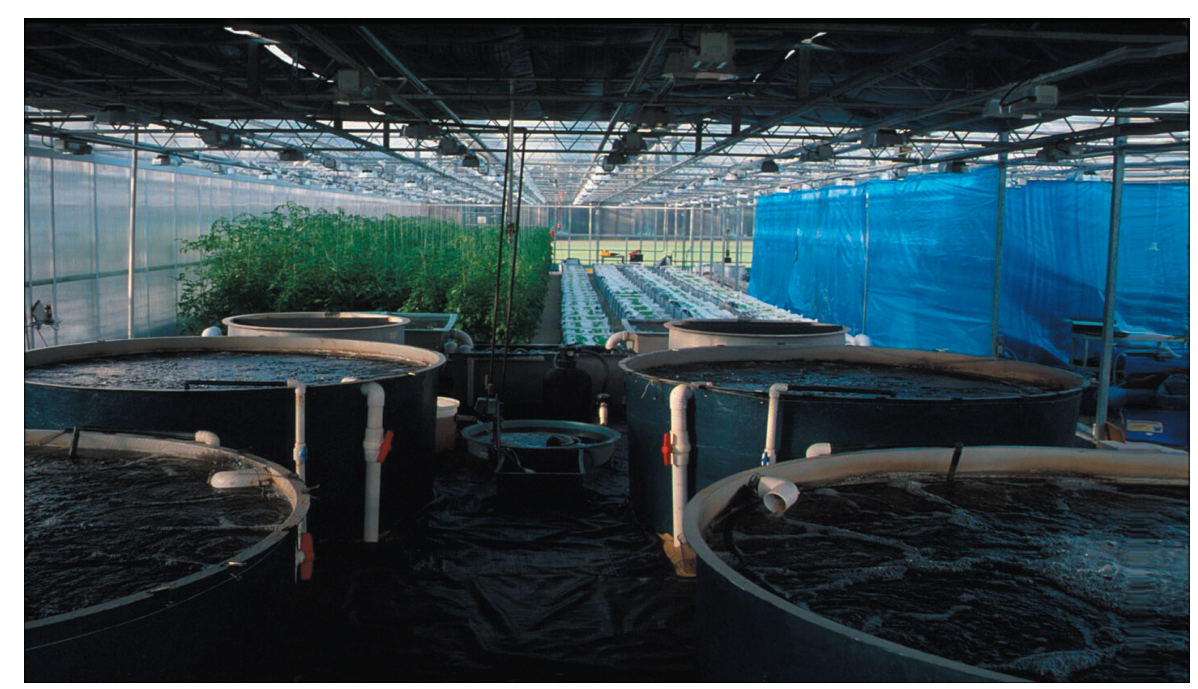

Fig. 4. The demonstration aquaponic system at the BCRRC site. Shown are the tilapia tanks, solid filtration (settling) tanks, and hydroponic crop production system. The latter has eight troughs in a $9 \times 30$ 
greenhouse floors to prevent irrigation water from leaving the greenhouse and going into the ground.

- Double-wall acrylic sidewalls to reduce heat loss through the sides of the greenhouse

- High-pressure fog cooling system.

- Automated rolling benches or Dutch traysthat allow the crop to be brought to the workers in the headhouse and also allow for greater space use in the greenhouse.

- Recirculating hydroponic irrigation system.

- Glass and double layer polyethylene roofing in identical sections to allow for comparison of crop production under both covers.

These technologies serve to give the greenhouse a soft footprint on the environment.

With more than $4,000 \mathrm{~m}^{2}$ of greenhouse production space, and about $900 \mathrm{~m}^{2}$ of support buildings, it is one of the largest research greenhouses in the United States. Research at the greenhouse focuses on the demonstration and transfer of new technologies in the environment and controlled environment agriculture areas, such as described here, and has also served a test facility for hydroponic limited-cluster tomato production (Logendra et al., 2001).

\section{Aquaponics}

Aquaponics is the combined culture of fish and plants in a recirculating system, whereby the aquaculture effluent is treated and recycled as a nutrient source for the plants. In general, the sharing of related operational and infrastructure costs also results in savings for the coupled system. The demonstration system at the BCRRC site is based on a working system at the University of the Virgin Islands, and is still in its test phase (Fig. 4). The system uses tank culture of tilapia, which grow well at high densities when good water quality is maintained and a complete diet provided (Rakocy, 1989).

Basically, dissolved waste nutrients from the fish are recovered by the plants, thereby reducing make-up water requirements and wastewater discharge to the environment. Stand-alone recirculating aquaculture systems require exchange of about $5 \%$ to $10 \%$ of the tank water volume daily, whereas aquaponic systems may operate with a daily water loss of $2 \%$ or less, with this water being lost through effluent sludge removal, tank water evaporation, and evapotranspiration from the hydroponic crop production. The aquaponic system aerates, filters and recycles the water, removing solid and toxic wastes. A biofilter converts toxic ammonia to nitrate, which is relatively nontoxic to fish, and is recirculated through the fish-plant system. The system is sized so that nitrate concentrations in the tanks stay well below toxic levels. Daily application of fish feed provides a steady, indirect supply of nutrients to the plants as well, thereby mitigating the need to replace depleted nutrient solutions (Rakocy, 1999). Initial trials at the BCRRC site have focused on tomato and lettuce production, and have found certain micronutrients to be the only fertilizer additions needed.

\section{Vermicompost}

Vermicomposts are produced from the fragmentation of organic wastes by earthworms, containing nutrients in forms readily available for plant uptake such as nitrates, exchangeable phosphorus, and soluble potassium, calcium and magnesium. They have a fine particulate structure, with high porosity, aeration, drainange and water-holding capacity. Whether as an amendment to soils or greenhouse container media, vermicomposts thus have potential beneficial effects on plant growth (Atiyeh et al., 2000). For the BCRRC site, both the sludge resulting from the filtered aquaculture effluent and the inedible biomass from plants harvested in the greenhouse are vermicomposted. Rather than being sent to the landfill as organic waste, these materials potentially contribute to marketable products such as soil amendments and liquid plant fertilizer (www. terracycle.ca).

\section{Algal culture}

Emissions of greenhouse gases and smog producing pollutants are an environmental concern. There are several sources for these gases, a major one being exhaust gases from electric power generators. Carbon dioxide from the microturbine exhaust (which is $5 \% \mathrm{CO}_{2}$ by volume) may be recovered for greenhouse enrichment. Alternatively, algal culture may be used to assimilate some of this $\mathrm{CO}_{2}$, and possibly some of the nitrogen from the $\mathrm{NO}_{\mathrm{X}}$ in the turbine exhaust into biomass (www.greenfuelonline.com). The algal biomass produced from this process may potentially be used as a renewable fuel source (e.g., biodiesel), and also as a feed supplement for aquaculture, which would make the BCRRC system more self-contained.

\section{Discussion}

The various projects described in this paper are in the demonstration stage, with most ongoing at the time of writing. It remains for rigorous analyses to be conducted on a proven system. Such would include life-cycle, energy-materials flow and economic studies, that would include, for instance, embodied energy in material product construction and transport. What is presented here, rather, is the preliminary stage of an integrated controlled environment agriculture system that uses landfill gas for energy, a source that would otherwise be flared. By integrating and recycling energy and materials, the system described would generate less waste in need of disposal and displace fossil fuel use.

In practice, displacing fossil fuel use would mitigate negative environmental impacts such as $\mathrm{SO}_{\mathrm{x}}, \mathrm{NO}_{\mathrm{x}}$, particulates and greenhouse gas emissions. The resulting emission credits are thus another potentially useful factor inherent in this systems approach. Other incentives would include, for instance, a pricing premium for the generated electricity that would help defray the costs of landfill gas-to-energy projects, increasing their economic feasibility and making them more competitive with fossil fuel electricity generation. However, the availability of research funds are imperative to test and prove systems such as those described here so that their potential may be realized.

\section{Literature Cited}

Atiyeh, R., S. Subler, C. Edwards, G. Bachman, J. Metzger, and W. Shuster. 2000. Effects of vermicomposts and composts on plant growth in horticultural container media and soil. Pedo biologia 44:579-590.

Britz, T. 1995. Landfill leachate treatment. In: E. Senior (ed.). Microbiology of landfill sites. CRC Press, Boca Raton, Fla.

Dixon, R., J. Winjum, K. Andrasko, J. Lee, and P. Schroeder. 1994. Integrated land-use systems: Assessments of promising agroforest and alternative land-use practices to enhace carbon conservation and sequestration. Climate Change 27:71-92.

Logendra, L., T. Gianfagna, and H. Janes. 2001. Using mini-rockwool blocks as a growing media for limited-cluster tomato production. HortTechnology 11(2):175-179.

Rakocy, J. 1999. Aquaculture engineering - The status of aquaponics. Part 1. Aquacult. Mag. (July/August):83-88.

Rakocy, J. 1989. Tank culture of tilapia. V.I. Agr. Expt. Sta., S. Reg. Aquacult. Ctr. Publ. 282.

U.S. EPA. 2001. MSW factbook. ver. 4.0. Office of Solid Waste, USEPA, Wash., DC.

U.S. EPA. 2003. U.S. Environmental Protection Agency Landfill Methane Outreach Program (LMOP), http://www.epa.gov/lmop/index.htm

White, P., M. Franke, and P. Hindle. 1995. Integrated solid waste management: A lifecycle inventory. Chapman \& Hall, U.K. 